\title{
Synthesis, spectral properties and DNA binding and nuclease activity of lanthanide (III) complexes of 2-benzoylpyridine benzhydrazone: $X$-ray crystal structure, Hirshfeld studies and nitrate- $\pi$ interactions of cerium(III) complex
}

\author{
KARREDDULA RAJA, AKKILI SUSEELAMMA and KATREDDI HUSSAIN REDDY* \\ Department of Chemistry, Sri Krishnadevaraya University, Anantapur 515 003, India \\ e-mail: khussainreddy@yahoo.co.in
}

MS received 24 June 2015; revised 20 August 2015; accepted 14 October 2015

\begin{abstract}
The lanthanide(III) complexes of general formula of $\left[\mathrm{Ln}(\mathrm{BPBH})_{2}\left(\mathrm{NO}_{3}\right)_{3}\right]$ (where, $\mathrm{Ln}=\mathrm{La}, \mathrm{Ce}$, $\mathrm{Pr}, \mathrm{Nd}$ and $\mathrm{BPBH}=2$-benzoylpyridine benzhydrazone) have been synthesized and characterized by elemental analysis, molar conductance, spectroscopic (UV, IR), electrochemical and single crystal X-ray diffraction studies. The coordination mode of the ligand and the geometry of $\left[\mathrm{Ce}(\mathrm{BPBH})_{2}\left(\mathrm{NO}_{3}\right)_{3}\right]$ are confirmed by single crystal X-ray studies. The crystals are monoclinic with $\mathrm{C} 2 / \mathrm{c}$ crystallographic symmetry. The central metal is 12 coordinated and the coordination polyhedron around the cerium atom can be described as a distorted icosahedron. The existence of nitrate. . $\pi$ and $\mathrm{CH} . . . \pi$ stacking interactions in the $\left[\mathrm{Ce}(\mathrm{BPBH})_{2}\left(\mathrm{NO}_{3}\right)_{3}\right]$ leads to a supramolecular arrangement in its network. The binding properties of these complexes with calf-thymus DNA have been investigated by viscosity measurements. The complexes show more nuclease activity in the presences of $\mathrm{H}_{2} \mathrm{O}_{2}$.
\end{abstract}

Keywords. Lanthanide(III)complexes; 2-benzoylpyridine benzhydrazone; structure determination; 12-coordinated cerium complex; DNA binding, supramolecular interactoions.

\section{Introduction}

Supramolecular architectures formed by covalent and non-covalent interactions have received considerable attention ${ }^{1-10}$ due to their visual beauty as well as applicability in versatile fields like biomimetic chemistry, solid state chemistry, materials and liquid crystal research. These weak supramoleulcar interactions (hydrogen bonding, C-H... $\pi$. Cation $-\pi$, anion $-\pi, \pi-\pi$ stacking, halogen-halogen, sulfur-sulfur and gold-gold) are being increasingly utilized to generate self-assembled structures. In this context, suitably designed multidenate ligands with assorted functionalities like NNO donor pyridine based hydrazones are of utmost importance. A great interest for NNO donor pyridine based hydrazones and their metal complexes has been motivated by a wide variety of biological and pharmaceutical activities, such as anticancer, antitumor, antimicrobial and anti-proliferative agents. ${ }^{11-16}$

The interactions of metal complexes with DNA suggest that the complexes may have potential biological and pharmaceutical activity depending on the mode of binding and affinity of binding with DNA. ${ }^{17-19}$ When designing potential anticancer agents, non-intercalative

\footnotetext{
*For correspondence
}

metal complexes are overlooked in favour of metallointercalators. However, bulky molecules yielded highly active anticancer agents that interact with DNA grooves. Given the success of groove binders, ${ }^{20-22}$ in cancer therapy, it is considered worthwhile to explore the present complexes as groove binders. The interaction of metal complexes with DNA is an area of passionate curiosity to both inorganic chemists and biochemists. Over the past decade, the DNA-binding metal complexes have demonstrated that inorganic complexes can be used for foot-printing studies ${ }^{23}$ as sequence specific DNA cleaving agents, ${ }^{24}$ as diagnostic agents in medicinal applications ${ }^{25}$ and for genomic research. ${ }^{26,27}$ The DNA binding and cleavage properties of lanthanide complexes under physiological conditions ${ }^{28,29}$ have attracted much attention and curiosity of bioinorganic chemists.

Coordination chemistry of lanthanides has developed into a wide variety of applications. Lanthanide(III) complexes are used in materials science and biology ${ }^{30}$ supramolecular luminescent sensors and self-assemblies ${ }^{31}$ contrast enhancing agents in radiopharmaceuticals, as MRI agents ${ }^{32}$ and in medicine. ${ }^{33}$ In the light of the above and in continuation of our ongoing research work, ${ }^{34-38}$ herein, we report synthesis, spectral characterization, 
DNA binding studies and intermolecular interaction of $\mathrm{La}(\mathrm{III}), \mathrm{Ce}(\mathrm{III}), \mathrm{Pr}(\mathrm{III})$ and $\mathrm{Nd}(\mathrm{III})$ complexes with 2-benzoylpyridine benzhydrazone (BPBH). Groove binding of complexes with DNA and the X-ray crystal structure determination of 12-coordinate $\mathrm{Ce}$ (III) complex are major highlights in this paper.

\section{Experimental}

\subsection{Materials and Methods}

All the reagents used in the synthesis of ligand (viz. 2benzoylpyridine, and benzhydrazide) and lanthanide nitrates were purchased from Sigma-Aldrich and were used without further purification. The solvents were obtained after being distilled by standard method. CT-DNA was purchased from Genie Biolabs, Bangalore, India.

The elemental analyses were performed using a Heraeus Vario EL III Carlo Erba 1108 instrument. The molar conductance of the complexes in DMF $\left(10^{-3} \mathrm{M}\right)$ solution was measured at $28^{\circ} \mathrm{C}$ with a Systronic model 303 direct-reading conductivity bridge. The electronic spectra were recorded in DMF with a Perkin Elmer UV Lamda-50 spectrophotometer. FT-IR spectra in $\mathrm{KBr}$ disc were recorded in the range $4000-400 \mathrm{~cm}^{-1}$ with a Perkin Elmer spectrum 100 spectrometer. The cyclic voltammetry was performed with a $\mathrm{CH}$ instrument 660C Electrochemical analyzer and a conventional three electrode assembly, $\mathrm{Ag} / \mathrm{AgCl}(1 \mathrm{M} \mathrm{KCl})$ as reference electrode, glassy carbon as working electrode and platinum as counter electrode. The $\mathrm{E}_{1 / 2}$ of ferrocence with respect to $\mathrm{Ag} / \mathrm{AgCl}$ electrode is $0.38 \mathrm{~V}$. Nitrogen gas was purged and measurements were made on the degassed $\left(\mathrm{N}_{2}\right.$ bubbling for $5 \mathrm{~min})$ complex solution in DMF $\left(10^{-3} \mathrm{M}\right)$ containing $0.1 \mathrm{M}$ tetrabutylammonium hexaflourophosphate (TBAHEP) as the supporting electrolyte.

\subsection{Synthesis of Ligand}

A methanolic solution of benzhydrazide $(0.68 \mathrm{~g}, 5$ mmol) was refluxed with 2-benzoyl pyridine $(0.916 \mathrm{~g}$,
$5 \mathrm{mmol}$ ) continuously for $4 \mathrm{~h}$. After adding a few drops of glacial acetic acid, there was no immediate formation of the product. Then the reaction mixture was kept aside for slow evaporation at room temperature. After 1 day white crystalline product was obtained. The compound was collected by filtration, washed with hot water and recrystallized from methanol and dried in vacuum. Analytical data of $\mathrm{BPBH}$ are given in table 1 . The ${ }^{1} \mathrm{H}-\mathrm{NMR}$ spectra $\left(\mathrm{CDCl}_{3}, \mathrm{ppm}\right), \delta 7.40$ (singlet, $\left.1 \mathrm{H}\right), \delta 7.42-8.80$ ) (multiplet $14 \mathrm{H}$ ), are respectively assigned to $>\mathrm{NH}$ and aromatic (pyridine + phenyl ring) protons. LCMS spectrum of BPBH showed molecular ion peak at $(m / z) 301$.

\subsection{Synthesis of Metal complexes}

The lanthanide complex was prepared by mixing hot ethanolic solution of BPBH (2 mmol, $0.602 \mathrm{~g})$ and $\mathrm{Ln}\left(\mathrm{NO}_{3}\right)_{3} \cdot 6 \mathrm{H}_{2} \mathrm{O}(1 \mathrm{mmol})$ dissolved in ethanol in $2: 1$ ratio in a clean $100 \mathrm{~mL}$ round bottom flask and the contents were refluxed at $60^{\circ} \mathrm{C}$ on water bath for 1-2 days. There was no formation of the product. Then the reaction mixture was kept aside at room temperature. After a few days, product was obtained. The complex was collected by filtration, washed with a small quantity of ether. Yellow coloured, needle shaped single crystals of Cerium complex were obtained on slow evaporation of the ethanol solution at room temperature. These crystals are suitable for X-ray diffraction studies. Analytical data are shown in table 1 .

\section{$2.4 X$-ray crystallography}

Crystal data were collected by using the Enraf Nonius CAD4-MV31 single crystal X-ray diffractometer, Indian Institute of Technology-Madras, Chennai. The detector is a scintillation counter. A single crystal is mounted on a thin glass fibre fixed on the goniometer head. The unit cell dimensions and orientation matrix are determined using 25 reflections and then the intensity data of a given set of reflections are collected automatically by the computer. Maximum $\mathrm{X}$-ray power is $40 \mathrm{~mA} \times 50 \mathrm{KV}$.

Table 1. Infrared spectral data $\left(\mathrm{cm}^{-1}\right)$ for the BPBH ligand and its lanthanide(III) complexes.

\begin{tabular}{lcccccccc}
\hline & & & & \multicolumn{5}{c}{$v\left(\mathrm{NO}_{3}^{-}\right)$} \\
\cline { 6 - 9 } Compound & $v(\mathrm{~N}-\mathrm{H}$ & $v(\mathrm{C}=\mathrm{O})$ & $v(\mathrm{C}=\mathrm{N})$ & $v_{1}\left(\mathrm{NO}_{3}^{-}\right)$ & $v_{4}\left(\mathrm{NO}_{3}^{-}\right)$ & $v_{2}\left(\mathrm{NO}_{3}\right)$ & $v_{3}\left(\mathrm{NO}_{3}^{-}\right)$ & $v_{1}-v_{4}$ \\
\hline $\mathrm{BPBH}$ & 3100 & 1673 & 1583 & $\ldots$ & $\ldots$ & $\ldots$ & $\ldots$ & \\
$\left.\mathrm{La}(\mathrm{BPBH})_{2}\left(\mathrm{NO}_{3}\right)_{3}\right]$ & 3199 & 1634 & 1536 & 1470 & 1301 & 1028 & 816 & 169 \\
{$\left[\mathrm{Ce}(\mathrm{BPBH})_{2}\left(\mathrm{NO}_{3}\right)_{3}\right]$} & 3197 & 1632 & 1536 & 1469 & 1300 & 1028 & 815 & 169 \\
{$\left[\mathrm{Pr}(\mathrm{BPBH})_{2}\left(\mathrm{NO}_{3}\right)_{3}\right]$} & 3211 & 1636 & 1538 & 1470 & 1301 & 1028 & 817 & 169 \\
{$\left[\mathrm{Nd}(\mathrm{BPBH})_{2}\left(\mathrm{NO}_{3}\right)_{3}\right]$} & 3198 & 1636 & 1539 & 1470 & 1302 & 1028 & 816 & 168 \\
\hline
\end{tabular}


The data collected were reduced using sainT program. ${ }^{39}$ The trial structure was obtained by direct met$\operatorname{hod}^{40}$ using SHELXS-86, which revealed the position of all non-hydrogen atoms and refined by full-matrix least squares on $\mathrm{F}^{2}$ (SHELXS-97) ${ }^{41}$ and graphic tool was DIAMOND for windows. ${ }^{42}$ All non-hydrogen atoms were refined anisotropically, while the hydrogen atoms were treated with a mixture of independent and constrained refinements.

\subsection{DNA Binding studies}

Binding property of lanthanide complexes with calf thymus DNA was studied by UV-Vis spectroscopy. The interaction of the lanthanide complexes with CT-DNA was carried out in tris-buffer. Solution of CT-DNA in $(0.5 \mathrm{~m} M \mathrm{NaCl} / 5 \mathrm{~m} M$ Tris- $\mathrm{HCl} ; p \mathrm{H}=7.0)$ buffer gave absorbance ratio at $260 \mathrm{~nm}$ and $280 \mathrm{~nm}$ of 1.8-1.9 indicating that the DNA was sufficiently free of proteins. ${ }^{43}$ The DNA concentration per nucleotide was determined by absorption coefficient $\left(6600 \mathrm{dm}^{3} \mathrm{~mol}^{-1} \mathrm{~cm}^{-1}\right)$ at 260 $\mathrm{nm}$. Stock solutions stored at $4^{\circ} \mathrm{C}$ were used after no more than four days.

\subsection{Viscosity measurements}

Viscosity measurements were carried out using an Ostwald-type viscometer, thermostated in a water bath maintained at $25( \pm 0.1)^{\circ} \mathrm{C}$. The DNA concentration was kept constant in all samples, but the concentration of the complex was increased from 0 to $90 \mu \mathrm{M}$. The average flow time was obtained after three measurements. The relative viscosity of DNA in the presence of complex $(\eta)$ and the viscosity of DNA alone $\left(\eta_{0}\right)$ in $5 \mathrm{mM}$ Tris-HCl buffer medium was calculated using the relation $\eta=\left(t-t_{0}\right) / t_{0}$, where $t$ and $t_{0}$ are the observed flow time for each sample and buffer. The resulting data are presented by plotting relative viscosity $\left(\eta / \eta_{0}\right)^{1 / 3}$ vs $1 / \mathrm{R}$, where $\mathrm{R}=$ [DNA]/ [complex].

\subsection{DNA cleavage studies}

The Nuclease activity of lanthanide complexes was performed using agarose gel electrophoresis with $\mathrm{pBR}$
322 DNA. After incubation for $30 \mathrm{~min}$ at $37^{\circ} \mathrm{C}$, the samples were added to the loading buffer containing $0.25 \%$ bromophenol blue $+0.25 \%$ xylene cyanol + $30 \%$ glycerol, and solutions were loaded on $0.8 \%$ agarose gel containing $100 \mu \mathrm{g}$ of ethidium bromide. Electrophoresis was performed at $75 \mathrm{~V}$ in TBE buffer until the bromophenol blue reached to $75 \%$ of the length of the gel. Bands were visualized by UV Transilluminator and photographed. The efficiency of DNA cleavage was measured by determining the ability of the complex to form open circular (OC) or nicked circular (NC) DNA from its supercoiled (SC) form. The reactions were carried out under different conditions.

\section{Results and Discussion}

The ligand (BPBH) is prepared (scheme 1) by simple condensation of 2-benzoylpyridine and benzhydrazide. The colour, elemental analysis, melting point of the BPBH ligand, and its lanthanide(III) complexes are given table S1 (see Supplementary Information). The elemental contents are consistent with the proposed molecular formulae of the ligand and its complexes. All the lanthanide(III) complexes are stable in air and nonhygroscopic. The complexes are soluble in DMF and DMSO. The range of molar conductivity values (10-19 $\Omega^{-1} \mathrm{~cm}^{2} \mathrm{~mol}^{-1}$ ) for the complexes suggest that these are non-electrolytes. ${ }^{44}$

\subsection{IR Spectroscopy}

The FT- IR spectra of complexes in the region 4000-400 $\mathrm{cm}^{-1}$ are analysed in comparison with that of metalfree BPBH. The characteristic IR peaks of BPBH and its lanthanide complexes are given in table 1. IR spectra of the four complexes are strikingly similar in relative positions and intensities of the peaks, which suggest a close structural relationship among the compounds. The IR spectrum of the free ligand shows strong bands at 1673 and $1583 \mathrm{~cm}^{-1}$, which are attributable to stretching vibrations of the carbonyl group $(v(\mathrm{C}=\mathrm{O}))$ and

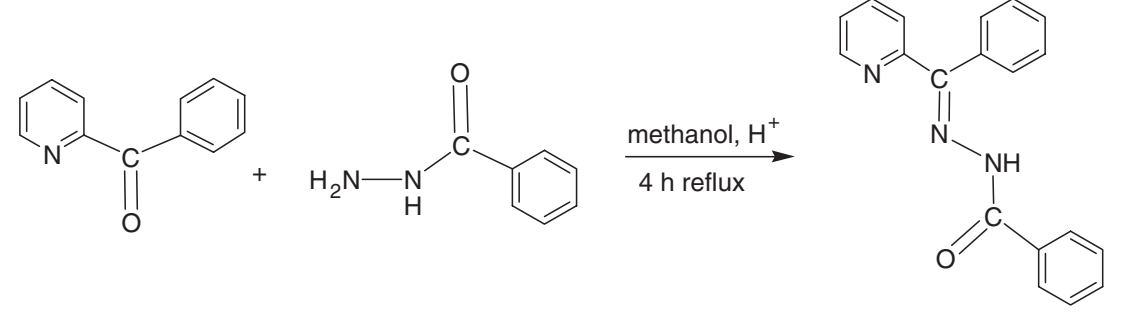

Scheme 1. Synthetic route of 2-benzoylpyridine benzhydrazone. 
$v(\mathrm{C}=\mathrm{N})$ of azomethine groups, respectively. In the IR spectra of lanthanide complexes, the $v(\mathrm{C}=\mathrm{O})$ and $v(\mathrm{C}=\mathrm{N})$ are shifted to lower frequencies (table 1). These shifts towards lower wave numbers indicate the participation of the carbonyl oxygen and azomethine nitrogen in coordination. ${ }^{45}$ The vibrational band at 3100 $\mathrm{cm}^{-1}$ can be assigned to the $v(\mathrm{~N}-\mathrm{H})$ for the free ligand. This $v(\mathrm{~N}-\mathrm{H})$ band is also observed (in the range $3197-$ $3211 \mathrm{~cm}^{-1}$ ) in the spectra of metal complexes. This observation suggests that the ligand remains in keto form in complexes. The pyridine ring in-plane deformation band is observed at $629 \mathrm{~cm}^{-1}$ in the spectrum of BPBH. This band shifts to $630-632 \mathrm{~cm}^{-1}$ in the spectra of lanthanide complexes indicating the involvement of pyridine nitrogen ${ }^{46}$ in chelation.

The above observations suggest that the BPBH acts as neutral tridentate ligand in complex formation. The absorption bands assigned to the coordinated nitrate groups $\left(C_{2 \mathrm{v}}\right)$ are observed in the range, $1469-1470 \mathrm{~cm}^{-1}$ $\left(v_{1}\right), 1300-1302 \mathrm{~cm}^{-1}\left(v_{4}\right), 1028 \mathrm{~cm}^{-1}\left(v_{2}\right)$ and $815-817$ $\mathrm{cm}^{-1}\left(v_{3}\right)$ for the nitrate complexes. The frequency separation $\left[\Delta v=v_{1}-v_{4}\right]$ between the asymmetric and symmetric stretching of nitrate group can be used to determine the binding mode. The $\Delta v$ values, 168-169 $\mathrm{cm}^{-1}$ suggest the bidentate nature of nitrate group ${ }^{47,48}$ The absence of band around $1385 \mathrm{~cm}^{-1}$ in IR spectra of complexes indicates the absence of ionic nitrate $\left(D_{3 \mathrm{~h}}\right.$ symmetry), which is in agreement with the results of the conductivity experiments. The new bands in $416-423 \mathrm{~cm}^{-1}$ and $541-546 \mathrm{~cm}^{-1}$ regions are assigned to $v(\mathrm{Ln}-\mathrm{O})$ and $v(\mathrm{Ln}-\mathrm{N})$ vibration, respectively.

\subsection{Electronic spectroscopy}

The electronic spectrum of the free ligand in UV region shows an intense band at $295 \mathrm{~nm}$ and a weaker band at $367 \mathrm{~nm}$ which are assigned to the $\pi-\pi^{*}$ and n$\pi *$ transitions, respectively. These bands are slightly shifted to either higher or lower frequencies in the spectra of lanthanide complexes. Electronic spectra of $\mathrm{Pr}(\mathrm{III}), \mathrm{Nd}(\mathrm{III})$ complexes are shown in figure $\mathrm{S} 1$ (see SI). Spectra show several important $\mathrm{f}-\mathrm{f}$ bands. The electronic spectra of the lanthanide complexes in the visible region exhibits red shift of the f-f bands relative to the corresponding $\operatorname{Ln}(\mathrm{III})$ aquo ion, shown in Figure $\mathrm{S} 2$. The shifts have been attributed to the covalent nature of metal-ligand bond present in lanthanide complexes. The values of the bonding parameters are shown in table $\mathrm{S} 2$. The positive and negative values of $\delta$ and $\mathrm{b}^{1 / 2}$ for a complex correspond to covalent and ionic characters, respectively. A nephelauxetic ratio $(\beta)$ of less than unity and positive values of Sinha's parameter $(\delta)$ and the bonding parameter $\left(b^{1 / 2}\right)$ suggest the occurrence of some covalent character in the metal- ligand bond. ${ }^{49,50}$ The low $(\delta \%)$ values of the complexes indicate weak covalent bonding in the complexes. the small $\mathrm{b}^{1 / 2}$ values suggest a minor participation of $4 \mathrm{f}$ orbitals in bonding.

\subsection{Description of the molecular structure of $\left[\mathrm{Ce}(\mathrm{BPBH})_{2}\left(\mathrm{NO}_{3}\right)_{3}\right]$}

$\left[\mathrm{Ce}(\mathrm{BPBH})_{2}\left(\mathrm{NO}_{3}\right)_{3}\right]$ crystallized in monoclinic space group $\mathrm{C} 2 / \mathrm{c}$ and the structure contains six neutral

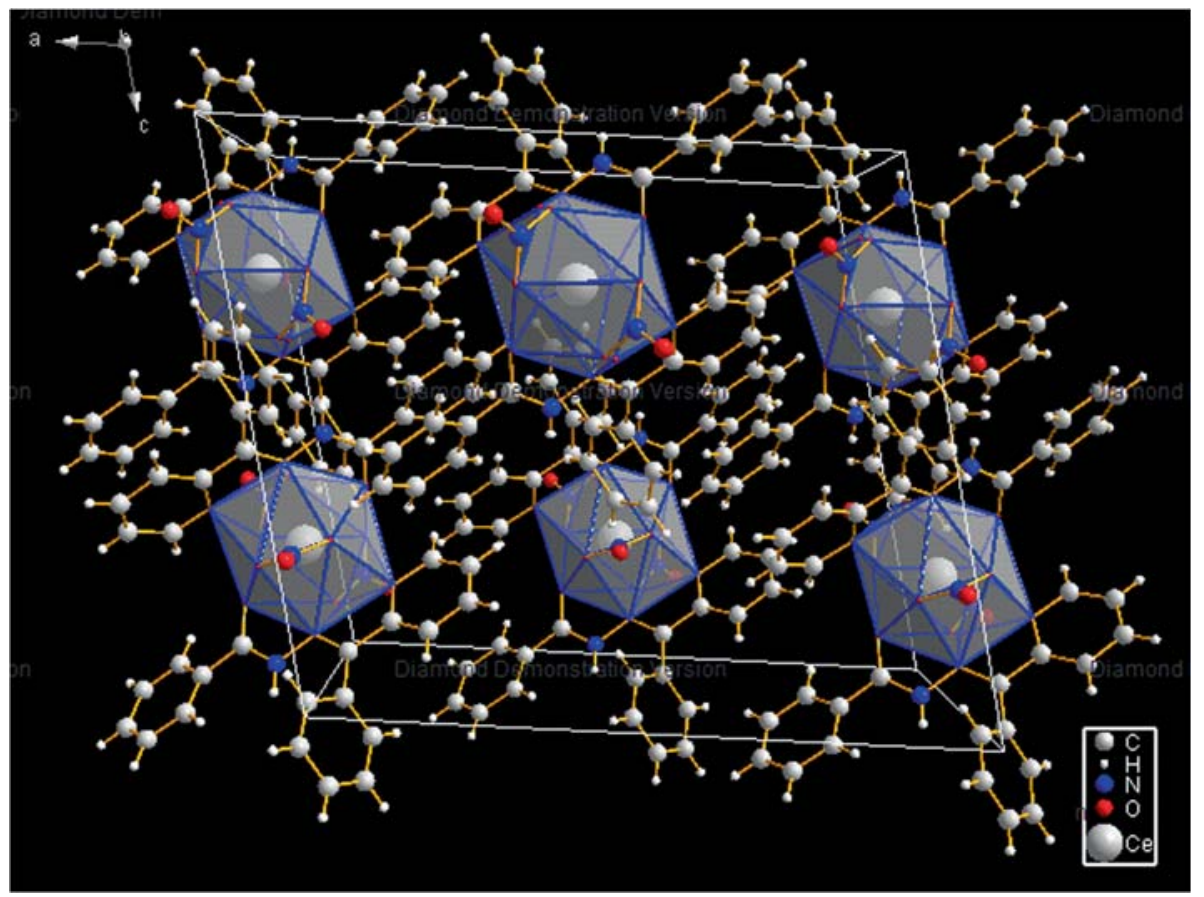

Figure 1. Unit cell structure of $\left[\mathrm{Ce}(\mathrm{BPBH})_{2}\left(\mathrm{NO}_{3}\right)_{3}\right]$ with distorted icosahedrons around $\mathrm{Ce}(\mathrm{III})$ centers. 
$\left[\mathrm{Ce}(\mathrm{BPBH})_{2}\left(\mathrm{NO}_{3}\right)_{3}\right]$ molecules in each unit cell as shown in figure 1. Crystal data and structure refinement parameters are shown in table 2. Selected bond lengths and bond angles are given in table 3. ORTEP view of $\left[\mathrm{Ce}(\mathrm{BPBH})_{2}\left(\mathrm{NO}_{3}\right)_{3}\right]$ together with the atom labeling scheme is used shown in figure 2. Cerium ion is surrounded by 12 coordinated donor atoms. Six of them belong to two neutral tridentate ligands and six from the three bidentate nitrate groups. The BPBH ligand is coordinated to central metal ion to form two fivemembered rings. One five-membered chelate ring involves the pyridine nitrogen and the azomethine nitrogen and another five-membered chelate ring involves the azomethine nitrogen and carbonyl oxygen donor atoms.

Generally, in 12 coordination complexes six polyhedra are considered: ${ }^{51}$ that is icosahedron, cuboctahedron, anticuboctahedron, hexagonal prism, hexagonal antiprism

Table 2. Crystal data and structure refinement parameters for $\left[\mathrm{Ce}(\mathrm{BPBH})_{2}\left(\mathrm{NO}_{3}\right)_{3}\right]$.

\begin{tabular}{|c|c|}
\hline Empirical formula & C38 H30 Ce N9 O11 \\
\hline Formula weight $\left(\mathrm{g} \mathrm{mol}^{-1}\right)$ & 928.83 \\
\hline Temperature $(\mathrm{K})$ & 293(2) \\
\hline Wavelength $(\AA)$ & 0.71073 \\
\hline Crystal system & Monoclinic \\
\hline space group & $C 2 / c$ \\
\hline \multicolumn{2}{|l|}{ Unit cell dimensions } \\
\hline $\mathrm{a}(\AA)$ & $18.5544(5)$ \\
\hline $\mathrm{b}(\AA)$ & $13.5066(4)$ \\
\hline$c(\AA)$ & $16.1009(4)$ \\
\hline$\alpha\left(^{\circ}\right)$ & 90 \\
\hline$\beta\left(\left(^{\circ}\right)\right.$ & $102.9450(10)$ \\
\hline$\gamma\left({ }^{\circ}\right)$ & 90 \\
\hline Volume $\left(\AA^{3}\right)$ & $3932.45(19)$ \\
\hline $\mathrm{Z}$ & 4 \\
\hline Calculated density (mg.m ${ }^{-3}$ ) & 1.569 \\
\hline Absorption coefficient $\left(\mathrm{mm}^{-1}\right)$ & 1.230 \\
\hline $\mathrm{F}(000)$ & 1868 \\
\hline Crystal size (mm) & $0.30 \times 0.20 \times 0.20$ \\
\hline$\theta$ range for data collection $\left(^{\circ}\right)$ & $2.25-24.99$ \\
\hline Limiting indices & $-22 \leq h \leq 22,-15 \leq k \leq 16,-12 \leq l \leq 19$ \\
\hline Reflections collected & $1 \overline{7} 721$ \\
\hline Unique & $3449\left[\mathrm{R}_{\mathrm{int}}=0.0283\right]$ \\
\hline Completeness to $\theta(\%)$ & 99.8 \\
\hline Absorption correction & Semi-empirical from equivalents \\
\hline Max. and min. transmission & 0.7995 and 0.7036 \\
\hline Refinement method & Full-matrix least-squares on $\mathrm{F}^{2}$ \\
\hline Data / restraints / parameters & 3449 / $56 / 298$ \\
\hline Goodness-of-fit on $F^{2}$ & 1.071 \\
\hline Final $R$ indices $[I>2 \sigma(I)]$ & $R 1=0.0183, \mathrm{w} R 2=0.0436$ \\
\hline$R$ indices (all data) & $R 1=0.0199, \mathrm{w} R 2=0.0443$ \\
\hline Largest diff. peak and hole (e $\AA^{-3}$ ) & 0.420 and -0.219 \\
\hline
\end{tabular}

Table 3. Selected bond lengths $(\AA)$ and angles $\left(^{\circ}\right)$ of $\left[\mathrm{Ce}(\mathrm{BPBH})_{2}\left(\mathrm{NO}_{3}\right)_{3}\right]$.

\begin{tabular}{lccc}
\hline Bond lengths $(\AA)$ & & \\
$\mathrm{N}(1)-\mathrm{Ce}(1)$ & $2.9365(16)$ & $\mathrm{N}(2)-\mathrm{Ce}(1)$ & $2.7706(14)$ \\
$\mathrm{O}(1)-\mathrm{Ce}(1)$ & $2.4952(12)$ & $\mathrm{O}(5)-\mathrm{Ce}(1)$ & $2.6808(14)$ \\
$\mathrm{Ce}(1)-\mathrm{O}(2)$ & $2.72(2)$ & $\mathrm{Ce}(1)-\mathrm{O}(4)$ & $2.62(2)$ \\
& & & \\
Bond Angles $\left(^{\circ}\right)$ & & & \\
$\mathrm{O}(1) \# 1-\mathrm{Ce}(1)-\mathrm{O}(1)$ & $176.89(6)$ & $\mathrm{O}(4) \# 1-\mathrm{Ce}(1)-\mathrm{O}(4)$ & $101.6(9)$ \\
$\mathrm{O}(2) \# 1-\mathrm{Ce}(1)-\mathrm{O}(2)$ & $71.5(6)$ & $\mathrm{O}(4)-\mathrm{Ce}(1)-\mathrm{O}(2) \# 1$ & $68.8(5)$ \\
$\mathrm{O}(4) \# 1-\mathrm{Ce}(1)-\mathrm{O}(2) \# 1$ & $48.4(5)$ & $\mathrm{O}(5)-\mathrm{Ce}(1)-\mathrm{O}(5) \# 1$ & $46.98(6)$ \\
\hline
\end{tabular}




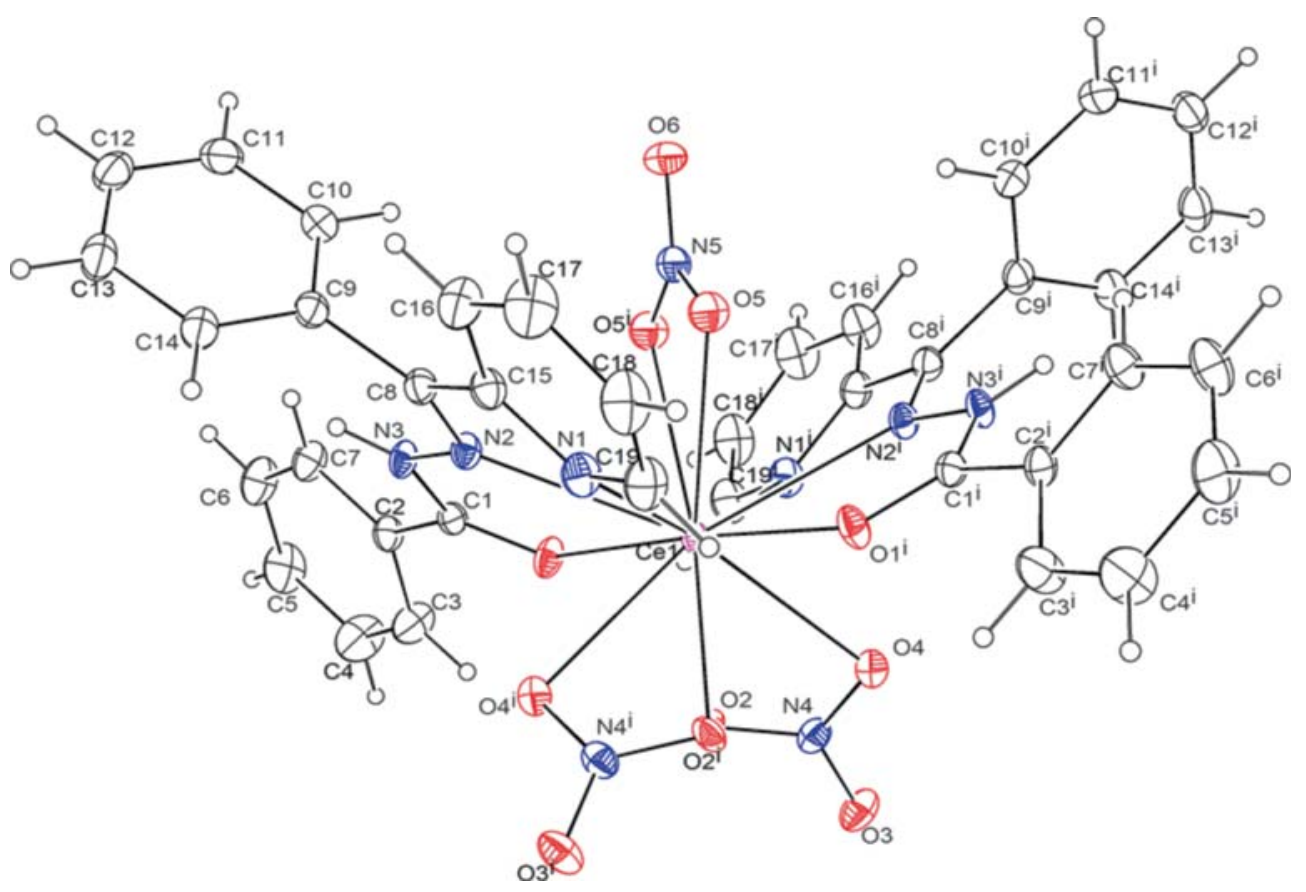

Figure 2. ORTEP view showing molecular structure of $\left[\mathrm{Ce}(\mathrm{BPBH})_{2}\left(\mathrm{NO}_{3}\right)_{3}\right]$ complex.

and bicapped pentagonal prism. $\left[\mathrm{Ce}(\mathrm{BPBH})_{2}\left(\mathrm{NO}_{3}\right)_{3}\right]$ shows that the geometry of 12-coordination is distorted icosahedron in which five triangles are joined at each vertex. In our case, the coordination polyhedron around $\mathrm{Ce}^{\mathrm{III}}$ is distorted icosahedron and is shown in figure 3.

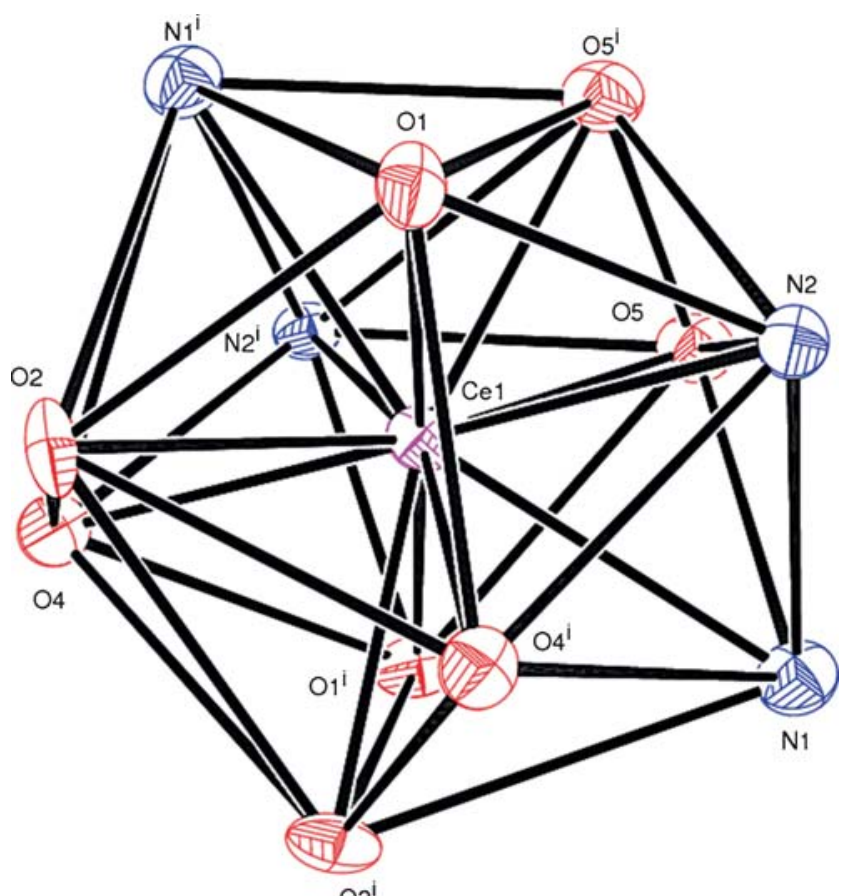

$\mathrm{O} 2^{\mathrm{i}}$

Figure 3. The coordination polyhedron (Distorted Icosahedron) around Cerium(III) ion in 12- coordinate $[\mathrm{Ce}(\mathrm{BPB}$ $\mathrm{H})_{2}\left(\mathrm{NO}_{3}\right)_{3}$ ] complex.
The regular icosahedron has 20 equilateral triangular faces, 12 vertices, 30 edges and five faces meet at each vertex. Each vertex figure is a regular pentagon. In our case, polyhedron containing 30 edges, 12 vertices and 20 faces (i.e., $\mathrm{V}-\mathrm{E}+\mathrm{F}=2$, Euler's formula, 12$30+20=2$ ) and five faces meet at each vertex. Each vertex figure is a pentagon. Twenty triangles deviate from the equatorial triangles, and also the vertex figure deviates from regular pentagon.

The phenyl rings adjacent to the 2-pyridyl ring are twisted out of this plane so as to avoid $\mathrm{H}-\mathrm{H}$ repulsion with the proton in the 3-position of the pyridyl ring. The Ce-O bond distances [2.4952(12) to 2.72(2) $\AA]$ are shorter than Ce-N [2.9365(16) to 2.7706(14) ̊]], as can expected for a hard oxygen donor bound to a lanthanide ion. ${ }^{52}$

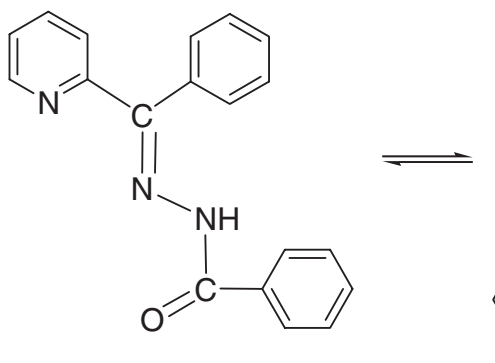

E<smiles>O=C(N/N=C(\c1ccccc1)c1ccccn1)c1ccccc1</smiles>

Z
Scheme 2. Geometrical isomers of 2-benzoylpyridine benzhydrazone. 
The Ce-N(py) distance is 2.9365(16) $\AA$ and Ce-N (azo) distance is $2.7706(14) \AA$. The difference may arise from constraints involved in chelate-ring formation or from the differing positions in which $\mathrm{N}(\mathrm{py})$ and $\mathrm{N}$ (azo) occupy in the polyhedron, as well as from differential $\mathrm{Ce} \rightarrow \mathrm{N}$ back donation. ${ }^{53}$ Cerium to donor atom bond length order is given below.

Ce-N(pyridine $)>$ Ce-N(azomethine $)$

$>$ Ce-O(Amide carbonyl) $>$ Ce-O(Nitrate)

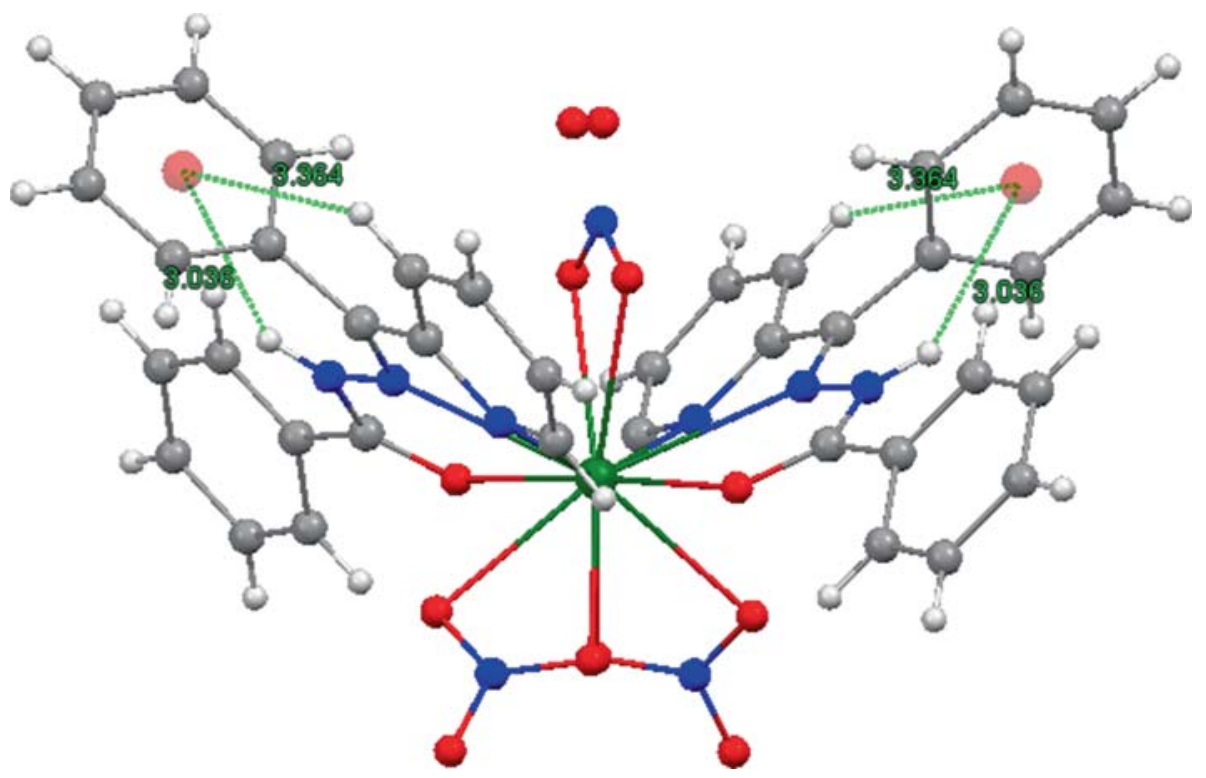

Figure 4. D-H. . $\pi$ intra molecular interactions for the Cerium complex.

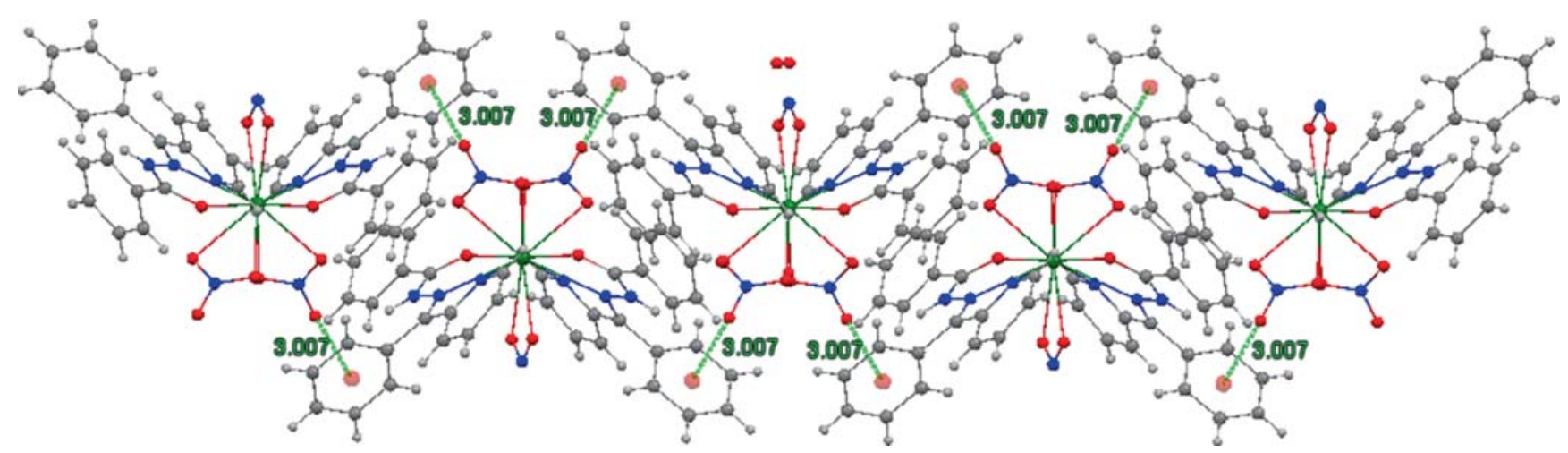

Figure 5. Intermolecular Nitrate $-\pi$ interactions of $\left[\mathrm{Ce}(\mathrm{BPBH})_{2}\left(\mathrm{NO}_{3}\right)_{3}\right]$.

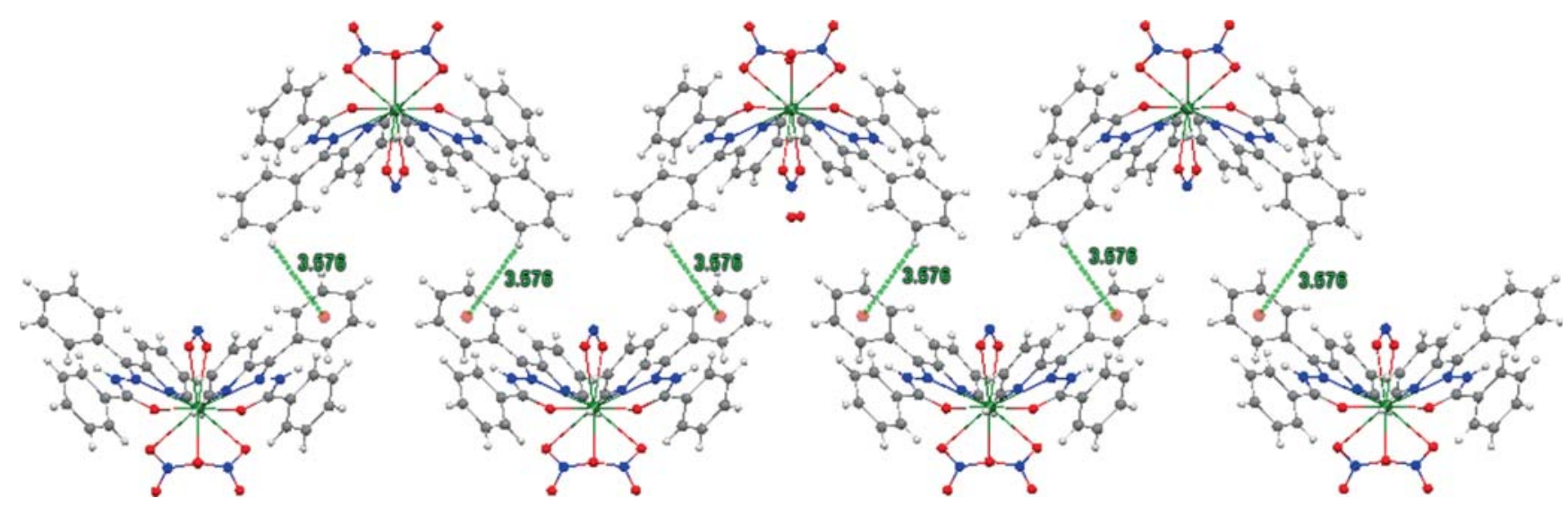

Figure 6. Intermolecular $\mathrm{CH}-\pi$ interactions of $\left[\mathrm{Ce}(\mathrm{BPBH})_{2}\left(\mathrm{NO}_{3}\right)_{3}\right]$. 
Three nitrates have metal to ligand bond angles which are nearly same but bond lengths are different. Based on bond lengths, three nitrates have two types of coordination, one type of two nitrates with unsymmetrical bond lengths [2.72(2) $\AA, 2.62(2) \AA]$, another type of nitrate bond lengths which are symmetrical [2.6808(14) Å].

Bond length data $[\mathrm{C}(1)-\mathrm{O}(1)] 1.231(2) \AA,[\mathrm{C}(1)-\mathrm{N}(3)$ $1.338(2) \AA]$ of the cerium complex indicate that the ligand binds to metal in keto form. It is well known that pyridine based hydrazones can exist as two geometrical isomers based on azomethine, syn (Z) and anti-(E) as shown in scheme 2 , but in our case, only the $\mathrm{E}$ isomer is possible in the cerium complex. The observed torsion angles $\mathrm{C} 15-\mathrm{C} 8-\mathrm{N} 2-\mathrm{N} 3\left(173.53^{\circ}\right)$, N2-N3-C1$\mathrm{O} 1\left(-4.45^{\circ}\right)$ support the hydrazone $\mathrm{E}$ conformation in coordination. ${ }^{54}$

The intra-molecular $\mathrm{C}-\mathrm{H} . . \pi$ interaction between the phenyl ring (adjacent to the 2-pyridyl ring) and pyridine hydrogen shows a distance of $3.364 \AA$. The intra-molecular $\mathrm{N}-\mathrm{H} . \ldots \pi$ interaction between the phenyl ring (adjacent to the 2-pyridyl ring) and imine hydrogen shows a distance of $3.036 \AA$. D-H. . . $\pi$ intramolecular interactions (where, $D=N / C$ ) for the Cerium complex are present as shown in figure 4.

Table 4. X-H... $\pi$ and Nitrate... $\pi$ interactions for the Cerium complex.

\begin{tabular}{lccc}
\hline D-H...A & $\mathrm{d}(\mathrm{H} \ldots \mathrm{A})$ & $\mathrm{d}(\mathrm{D} \ldots \mathrm{A})$ & $<(\mathrm{DHA})$ \\
\hline Intramolecular interactions & & & \\
$\mathrm{C}(16)-\mathrm{H}(17) \ldots \mathrm{Cg}(\mathrm{I})$ & 3.364 & 3.968 & 124.68 \\
$\mathrm{~N}(3)-\mathrm{H}(3 \mathrm{~A}) \ldots \mathrm{Cg}(\mathrm{I})$ & 3.036 & 3.635 & 128.62 \\
$\begin{array}{l}\text { Intermolecular interactions } \\
\mathrm{C}(11)-\mathrm{H}(12) \ldots \mathrm{Cg}(\mathrm{I})\end{array}$ & 3.576 & 4.183 & 125.26 \\
Nitrate. ... interactions & & & \\
$\mathrm{N}(4)-\mathrm{O}(3) \ldots \mathrm{Cg}(\mathrm{I})$ & 3.007 & 3.558 & 106.61 \\
$\mathrm{Cg}(\mathrm{I})=\mathrm{C} 9-\mathrm{C} 14$ ring & & & \\
\hline
\end{tabular}

Another interesting feature of the $\left[\mathrm{Ce}(\mathrm{BPBH})_{2}\right.$ $\left.\left(\mathrm{NO}_{3}\right)_{3}\right]$ complex is the presence of nitrate... $\pi$ and $\mathrm{CH} . . \pi$ interactions (figures 5 and 6). $\mathrm{O}_{\text {(nitrate) }} \ldots \pi$ edge-to-face interactions are present between oxygen atom of the nitrate group and phenyl ring with $\mathrm{O} \ldots \pi$ distance of $3.007 \AA$ for $\mathrm{N}(4)-\mathrm{O}(3) \ldots \mathrm{Cg}(\mathrm{I})[\mathrm{Cg}(\mathrm{I})$ is centroid for $\mathrm{C}(9) / \mathrm{C}(14)$ ring] (figure 5). Also, in the crystal packing $\mathrm{CH} \ldots \pi$ interactions exist between the hydrogen atom of the phenyl ring (2-benzoyl) and phenyl ring (2-benzoyl) of neighboring molecule, with $\mathrm{CH} . \ldots \pi$ distance of $3.576 \AA$ for $\mathrm{C}(11)-\mathrm{H}(12) \ldots . . \mathrm{Cg}(\mathrm{I})$ (figure 6). The details of intra- and intermolecular interactions are given in table 4.

In the cerium complex mainly $\mathrm{N}-\mathrm{H} \cdots \mathrm{O}$ type of strong intermolecular hydrogen bonds are present between the imine nitrogen and the oxygen atom (not involved in bond formation with metal) of coordinated nitrate ion. View of the hydrogen bond network of [Ce $(\mathrm{BPBH})_{2}\left(\mathrm{NO}_{3}\right)_{3}$ ] complex is shown in figure 7. Selected hydrogen bond lengths and angles are listed in table 5 .

The complex is well stabilized due to presence of intra molecular D-H. . . $\pi$ interactions, intermolecular $\mathrm{CH}-\pi$, niitrate..$\pi$ and Hydrogen bonding interactions.

\subsection{Hirshfeld surface analysis}

The Hirshfeld surfaces represented by $\mathrm{d}_{\text {norm }}$ range of red (distances shorter than sum of van der Waals (vdW) radii) through white to blue (distances longer than sum

Table 5. Hydrogen bonds $(\AA)$ and Angles $\left(^{\circ}\right)$ for the Cerium complex.

\begin{tabular}{lcccc}
\hline $\mathrm{D}-\mathrm{H} . . . \mathrm{A}$ & $\mathrm{d}(\mathrm{D}-\mathrm{H})$ & $\mathrm{d}(\mathrm{H} . . . \mathrm{A})$ & $\mathrm{d}(\mathrm{D} \ldots \mathrm{A})$ & $<(\mathrm{DHA})$ \\
\hline $\mathrm{N}(3)-\mathrm{H}(3 \mathrm{~A}) \ldots \mathrm{O}(3)^{\mathrm{a}}$ & 0.86 & 2.23 & $3.033(2)$ & 154.5 \\
\hline
\end{tabular}

${ }^{a}$ Symmetry transformations used to generate equivalent atoms: $\mathrm{x},-\mathrm{y}+1, \mathrm{z}-1 / 2$.

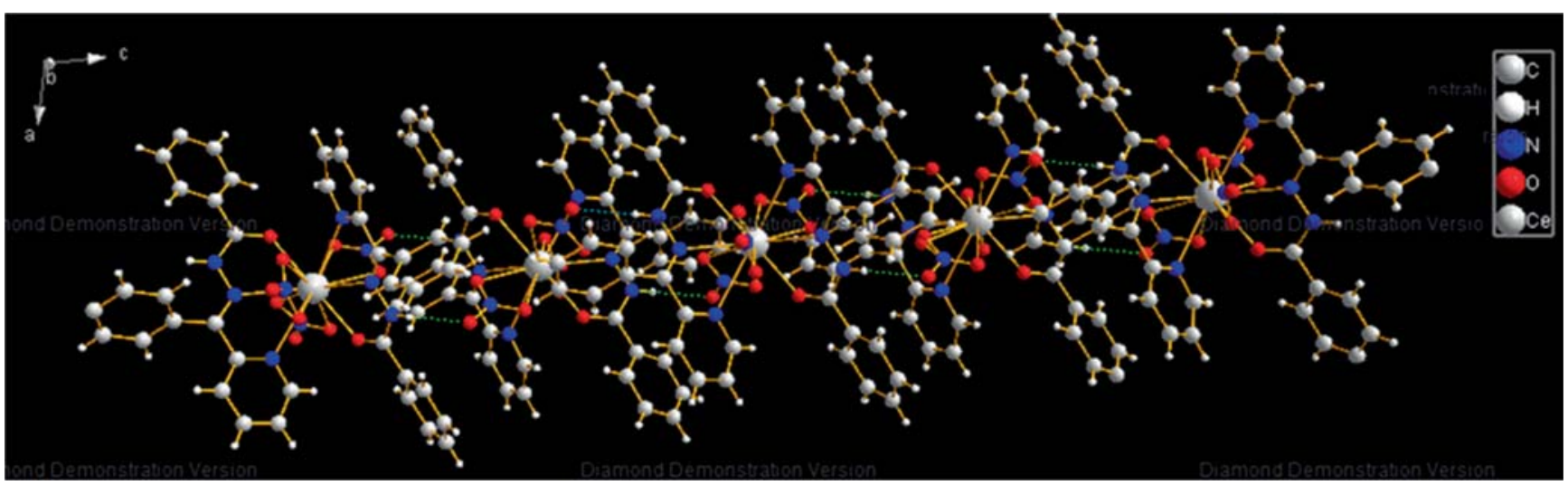

Figure 7. View of the Hydrogen bond (green dotted line) network of [Ce(BPBH $\left.)_{2}\left(\mathrm{NO}_{3}\right)_{3}\right]$. 
of $\mathrm{vdW}$ radii), shape index range of -1.0 (concave) through 0.0 (minimal surface) to +1.0 (convex), and 2-D fingerprint plots were calculated using Crystal Explorer 3.1. ${ }^{55}$

For each point on the Hirshfeld surface, two parameters are defined: $d_{e}$ from the point to the nearest nucleus external to the surface and $\mathrm{d}_{\mathrm{i}}$, the distance from the point to the nearest nucleus internal to the surface. The normalized contact distance, $d_{\text {norm }}$, based on both $d_{e}$ and $\mathrm{d}_{\mathrm{i}}$, and the vdW radius of the atom, is given by the equation:

$$
\mathrm{d}_{\text {norm }}=\frac{\mathrm{d}_{\mathrm{i}}-\mathrm{r}_{\mathrm{i}}^{\mathrm{Vdw}}}{\mathrm{r}_{\mathrm{i}}^{\mathrm{ddw}}}+\frac{\mathrm{d}_{\mathrm{e}}-\mathrm{r}_{\mathrm{e}}^{\mathrm{Vdw}}}{\mathrm{r}_{\mathrm{e}}^{\mathrm{Vdw}}}
$$

Here, $r_{i}^{\mathrm{Vdw}}$ and $\mathrm{r}_{\mathrm{e}}^{\mathrm{Vdw}}$ are the internal and external van der Waals radius of the atom. The Hirshfeld surface mapped over $\mathrm{d}_{\text {norm }}$ displays the intermolecular $\mathrm{NH}-$ $\mathrm{O}_{\text {(nitrate) }}$ interactions as bright red areas and on the $\mathrm{d}_{\text {norm }}$ surface, a light red colour indicates $\mathrm{CH}_{\text {(phenyl/Pyridine) }}{ }^{-}$ $\mathrm{O}_{\text {(nitrate) }}$ interactions in the cerium complex shown in figure 8.

In the 2-D fingerprint plots, two distinct spikes appear for $\mathrm{O} \ldots \mathrm{C} / \mathrm{C} \ldots \mathrm{O}$ intermolecular interactions. The proportion of O..C/C..O interactions comprises $4.2 \%$ of the total Hirshfeld surfaces for each molecule of Cerium complex. This region corresponds to $\mathrm{O}_{\text {(nitrate) }} \ldots \pi$ interaction in the fingerprint plot in a characteristic manner.

This decomposition enables separation of contributions from different interaction types, which overlap in the full fingerprint plot. In the 2-D fingerprint plots, two distinct spikes appear for O. .H/H. .O intermolecular interactions. The proportion of $\mathrm{O} \ldots \mathrm{H} / \mathrm{H}$. . O interactions comprises $27.3 \%$ of the total Hirshfeld surface for each molecule of the Ce complex. The upper spike corresponding to the donor represents the O...H interactions $\left(\mathrm{d}_{\mathrm{i}}=0.9, \mathrm{~d}_{\mathrm{e}}=1.2 \AA\right)$ and the lower spike being an acceptor represents the H. .O interactions $\left(d_{e}=0.9\right.$, $\mathrm{d}_{\mathrm{i}}=1.2 \AA$ in the Ce complex) in the fingerprint plot (figure 9). The decomposition of the fingerprint plot shows that C...H/H. .C contacts comprise $19.9 \%$ of the total Hirshfeld surface area for Ce complex. The region corresponds to all $\mathrm{C}-\mathrm{H}$...C interactions of which $\mathrm{C}-\mathrm{H} . . \pi$ appears in the fingerprint plot in a characteristic manner.

Hirshfeld surface of Ce complex does not show adjacent red and blue triangles on the shape-index surfaces (figure 8). This indicates absence of $\pi-\pi$ interactions. However some carbon carbon interactions are present which comprises $3.6 \%$ of the total Hirshfed surface area of the molecule. The proportion of H...H interactions comprises of $41.4 \%$ in 2D fingerprint plot.

\subsection{Electrochemical studies}

Redox behaviour of the lanthanide(III) complexes has been investigated by cyclic voltammetry using $0.1 \mathrm{M}$ tetrabutylammonium hexaflourophosphate (TBAHEP) as supporting electrolyte. The cyclic voltammetric profile of $\left[\mathrm{La}(\mathrm{BPBH})_{2}\left(\mathrm{NO}_{3}\right)_{3}\right]$ complex is given in figure 10a. A plot of $\mathrm{i}_{\mathrm{p}} \mathrm{vs} v^{1 / 2}$ ( $v$ is scan rate) is linear (figure 10b) pointing towards diffusion controlled nature of the reduction wave. In the reverse scan there is no anodic peak confirming the irreversible nature of electrode process. All these facts point towards the diffusioncontrolled nature of the electrode process.

The cyclic voltammograms of $\mathrm{La}(\mathrm{III}), \mathrm{Ce}(\mathrm{III})$. $\mathrm{Pr}$ (III) and $\mathrm{Nd}(\mathrm{III})$ gave irreversible waves. Their cathodic reduction peaks are found to be at $-1.08,-1.35,-0.88$ and $-1.0 \mathrm{~V}$ for $\mathrm{La}(\mathrm{III}), \mathrm{Ce}(\mathrm{III}), \operatorname{Pr}(\mathrm{III})$ and $\mathrm{Nd}(\mathrm{III})$, respectively. This is due to the reduction of $\operatorname{Ln}(\mathrm{III})$ to Ln(II) couple. ${ }^{56}$

\subsection{DNA binding studies}

To clarify the nature of the binding interaction between lanthanide complexes and DNA, viscosity measurements
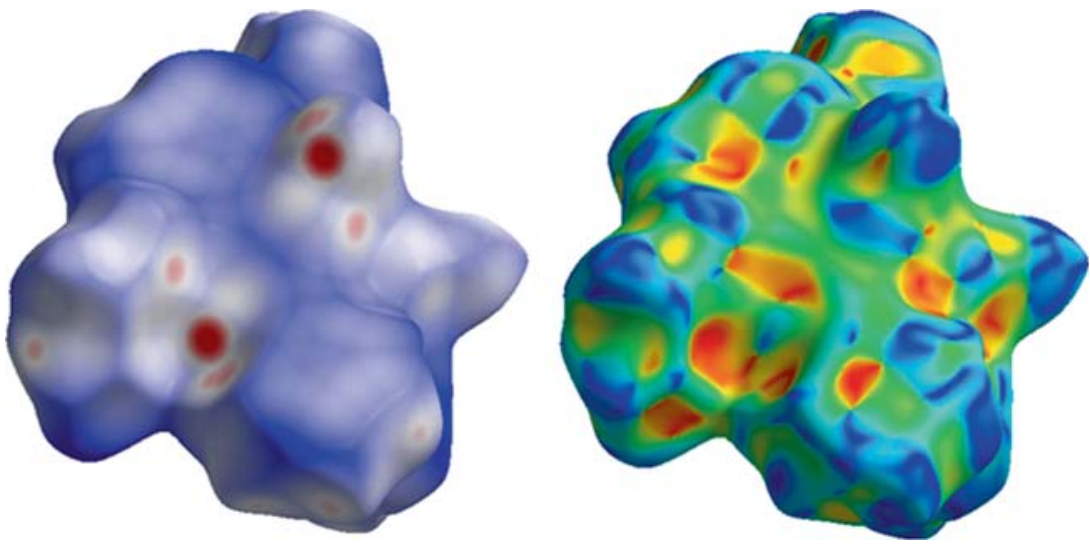

Figure 8. Hirshfeld surface mapped with (Left) $d_{\text {norm }}$ and (Right) shape index for the Ce complex. 

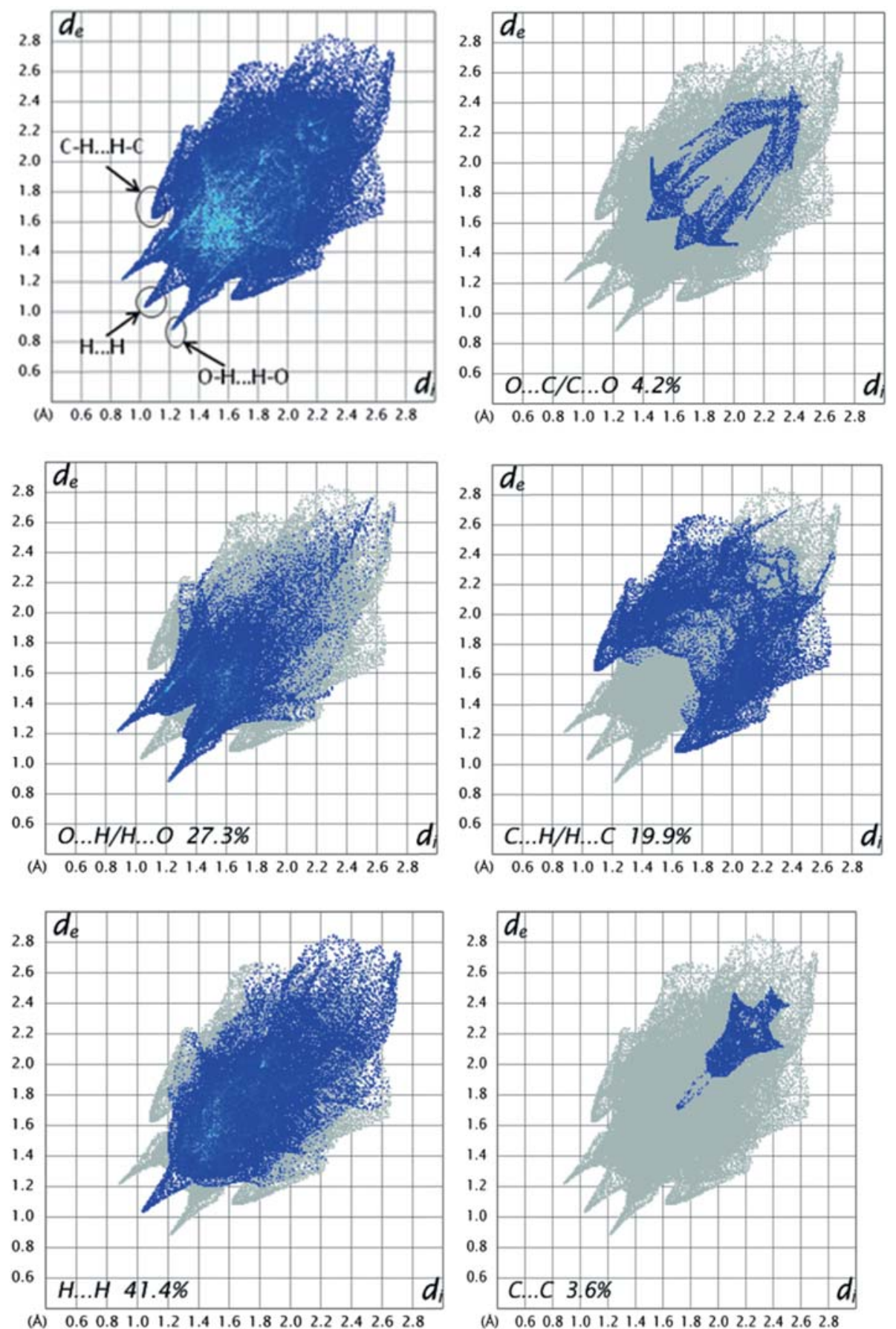

Figure 9. 2D fingerprint plots, full and resolved into $\mathrm{OC} / \mathrm{OC}, \mathrm{OH} / \mathrm{HO}, \mathrm{CH} / \mathrm{CH}, \mathrm{H} / \mathrm{H}$ and $\mathrm{C} / \mathrm{C}$ contacts showing percentages of contacts contributed to the total Hirshfeld surface area of the molecule.

were carried out on CT DNA by varying the concentration of the added complexes. The effect of addition of an increasing concentration of the lanthanide complexes and ligand on the relative viscosity of DNA is shown in figure 11. As can be seen in figure 11, upon increasing concentration of the lanthanide complexes and ligand, the relative viscosity of DNA increases steadily. The increasing degree of viscosity is as follows:

$$
\begin{aligned}
\text { Ligand } & <\text { Cerium Complex }<\text { La complex } \\
& <\text { Pr complex }<\text { Nd complex }
\end{aligned}
$$

Normally, intercalative/ groove binding agents increase the viscosity of DNA. The complexes cause a relatively large increase in the viscosity of DNA, which is consistent with DNA groove binding as suggested by Palaniandvar et al. ${ }^{57}$ Since the complexes are bulky and lack planarity, groove binding of the complexes 


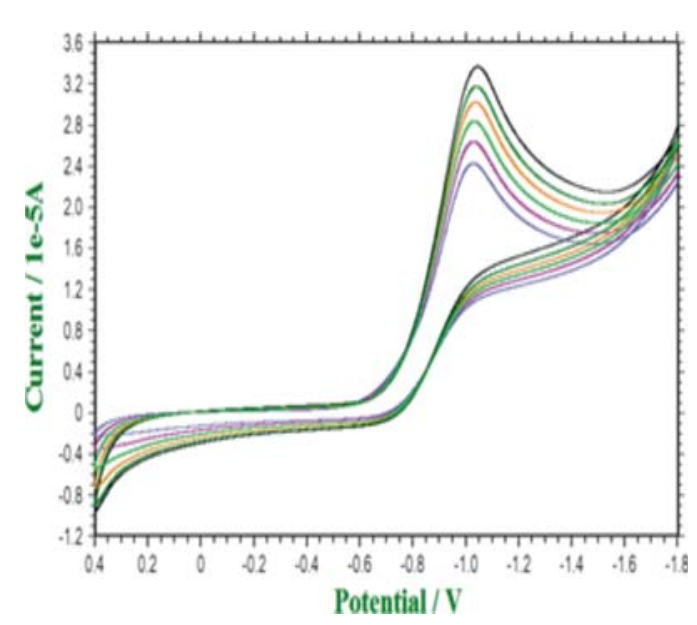

(a)

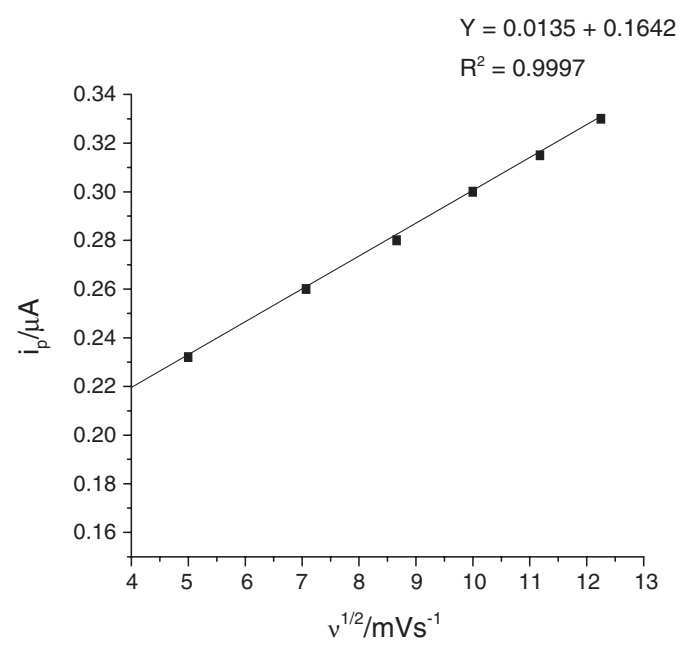

(b)

Figure 10. (a) CV profiles of the Lanthanum complex at different scan rates $25-150 \mathrm{mV} / \mathrm{s}$; (b) Plot of peak current vs square root of scan rate for Lanthanum complex.

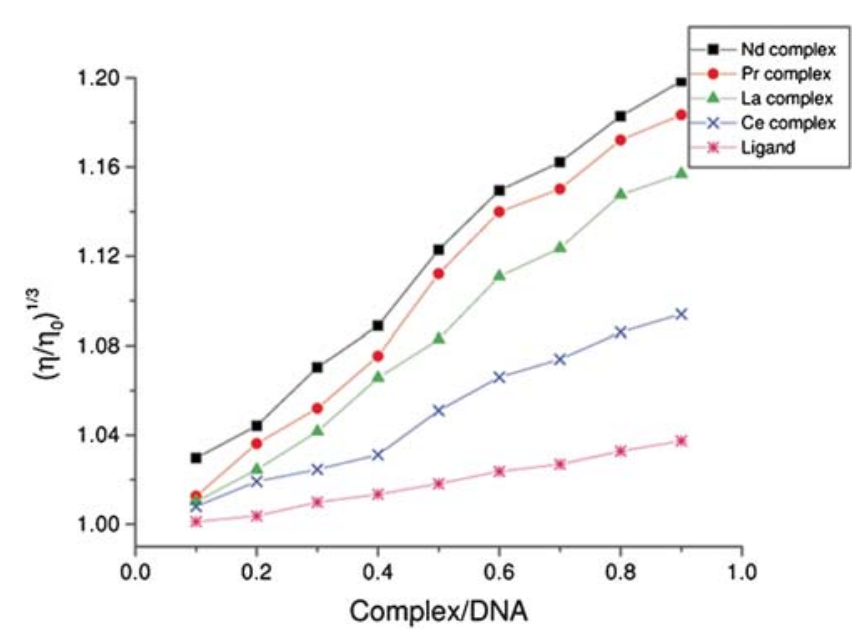

Figure 11. Effect of increasing amount of complexes of $\mathrm{Nd}, \mathrm{Pr}, \mathrm{La}$ and $\mathrm{Ce}$ and ligand $(0-90 \mu \mathrm{M})$ on the relative viscosity of CT DNA $(100 \mathrm{mM})$ at $25( \pm 0.1)^{\circ} \mathrm{C}$. with DNA was suggested ${ }^{57,58}$ rather than base-pair intercalation.

\subsection{DNA cleavage activity}

Nuclease activity of lanthanide complexes derived from 2-benzoylpyridine benzhydrazone (BPBH) has been studied by agarose gel electrophoresis using pBR 322 plasmid DNA in Tris- $\mathrm{HCl} / \mathrm{NaCl}(50 \mathrm{mM} / 5 \mathrm{mM})$ buffer(pH-7) in the presence and absence of $\mathrm{H}_{2} \mathrm{O}_{2}$ as an oxidant at micromolar concentration for $30 \mathrm{~min}$ incubation period at $37^{\circ} \mathrm{C}$. In the presence of $\mathrm{H}_{2} \mathrm{O}_{2}$ the supercoiled DNA (form I) is changed into nicked form (form II). Figure 12 shows the cleavage activity of lanthanide complexes.

In the presence of $\mathrm{H}_{2} \mathrm{O}_{2}$, the complexes cleave DNA more effectively [lanes 6, 8 and 10 in figure 12], which may be due to the reaction of hydroxyl radical with DNA by Fenton mechanism. ${ }^{59}$ These hydroxyl free radicals participate in the oxidation of the deoxyribose moiety, followed by hydrolytic cleavage of the sugar

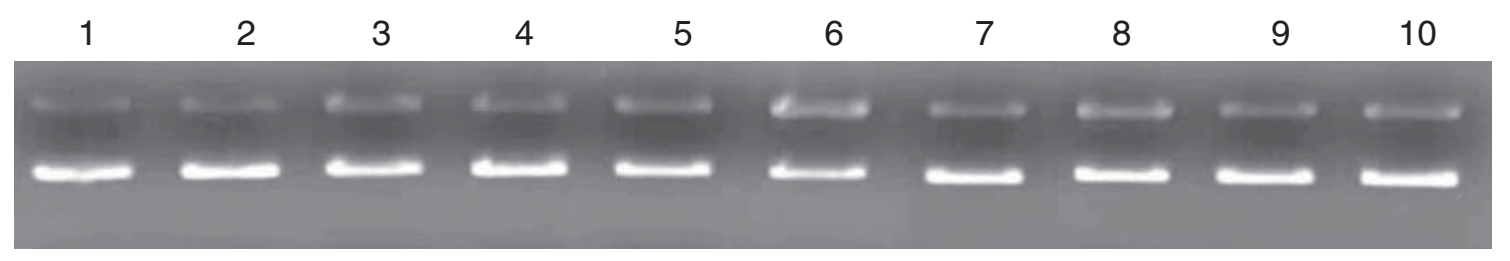

Figure 12. Agarose gel $(0.8 \%)$ showing results of electrophoresis of $1 \mu \mathrm{L}$ of pBR322 plasmid DNA; $4 \mu \mathrm{L}$ of Tris- $\mathrm{HCl} / \mathrm{NaCl}(50 \mathrm{mM} / 5 \mathrm{mM})$ buffer $(\mathrm{pH}-7) ; 2 \mu \mathrm{L}$ of complex in DMF $\left(1 \times 10^{-3} \mathrm{M}\right) ; 11 \mu \mathrm{L}$ of sterilized water; $2 \mu \mathrm{L}$ of $\mathrm{H}_{2} \mathrm{O}_{2}$ (total volume $20 \mu \mathrm{L}$ ) were added, respectively, and incubated at $37^{\circ} \mathrm{C}(30 \mathrm{~min})$; Lane 1: DNA control; Lane 2: DNA control $+\mathrm{H}_{2} \mathrm{O}_{2}$; Lane 3: La complex+ DNA; Lane 4: La complex + DNA $+\mathrm{H}_{2} \mathrm{O}_{2}$; Lane 5: Ce complex+ DNA; Lane 6: Ce complex+ DNA + $\mathrm{H}_{2} \mathrm{O}_{2}$; Lane 7: Pr complex + DNA; Lane 8: Pr complex+ DNA $+\mathrm{H}_{2} \mathrm{O}_{2}$; Lane 9: Nd complex+ DNA; Lane 10: Nd complex + DNA $+\mathrm{H}_{2} \mathrm{O}_{2}$. 
phosphate backbone. ${ }^{60}$ The order of activity in the presence of oxidant is as follows:

$$
\begin{aligned}
& \text { Ce complex }>\text { Pr complex } \\
& \quad>\text { Nd complex }>\text { La complex }
\end{aligned}
$$

\section{Conclusions}

Lanthanide complexes of 2-benzoylpyridine benzhydrazone (BPBH) have been synthesized and characterized. Physico-chemical and spectral studies reveal that the complexes have general formula $\left[\mathrm{Ln}(\mathrm{BPBH})_{2}\left(\mathrm{NO}_{3}\right)_{3}\right]$ (where $\mathrm{Ln}=\mathrm{La}, \mathrm{Ce}, \mathrm{Pr}$ and $\mathrm{Nd}$ ). $\mathrm{BPBH}$ acts as a neutral tridentate ligand and $\mathrm{NO}_{3}^{-}$acts as bidentate ligand. Two BPBH ligands occupy six coordination sites and three $\mathrm{NO}_{3}^{-}$ligands another six coordination sites to form 12coordinated mononuclear complexes. The structure of $\left[\mathrm{Ce}(\mathrm{BPBH})_{2}\left(\mathrm{NO}_{3}\right)_{3}\right]$ complex was determined by single crystal X-ray diffraction studies. Binding studies suggest groove binding of the complexes with DNA. The complexes show nuclease activity in the presences of $\mathrm{H}_{2} \mathrm{O}_{2}$.

\section{Acknowledgements}

KR is thankful to UGC, New Delhi for the award Project Fellowship. The authors are thankful to UGC, New Delhi [Sanction No. F 40-80/2011(SR)] for financial support. Authors are also thankful to SAIF, IITMadras for providing X-ray crystallographic data. KHR is thankful to UGC for the sanction of one-time financial grant [Sanction No. F.19-106/2013(BSR)]. The authors also thank UGC and DST for providing equipment facility under SAP and FIST programs.

\section{Supplementary Information}

CCDC 917957 contains the supplementary crystallographic data for Ce complex. These data can be obtained free of charge via http://www.ccdc.cam.ac. uk/conts/retrieving.html, or from the Cambridge Crystallographic Data Centre, 12 Union Road, Cambridge CB2 1EZ, UK; fax: +44 1223336 033; or e-mail: deposit@ccdc.cam.ac.uk. Figures S1 and S2 show the electronic spectra of complexes. Tables $\mathrm{S} 1$ and $\mathrm{S} 2$ give analytical and electronic spectral data respectively. Supplementary information is available at www.ias.ac.in/ chemsci

\section{References}

1. Baga D, Maini L, Polito M, Scaccianoce I, Cojazzi G and Grepiont F 2001 Coord. Chem. Rev. 216225
2. Davies J E D, MacNicol D D, Vogtle F and Toda R B 1996 In Comprehensive Supramolecular Chemistry (Oxford: Pergamon)

3. Thomas J A, Atwood J L and Steel J W 2004 In Encyclopedia of Supramolecular Chemistry (Boca Raton, FL: CRC Press) p. 1248

4. Desiraju G R 1994 Proc. Indian Acad. Sci. (J. Chem. Sci.) 106593

5. Ikkala O and Brinke G T 2002 Science 2952407

6. Moulton B and Zaworotko M J 2001 Chem. Rev. 101 1629

7. Lebrilla 2001 Acc. Chem. Res. 34653

8. Nayak M, Koner R, Stoeckli-Evans H and Mohanta S 2005 Cryst. Growth Des. 51907

9. Kato T 2002 Science 2952414

10. Moulton B and Zaworotko M J 2002 Curr. Opin. Solid State Mater. Sci. 6117

11. Easmon J, Purstinger G, Thies K S, Heinisch G and Hofmann J 2006 J. Med. Chem. 496343

12. Angel A R D, Gabrieli I P, Jans B I, Pryscila R D, Raquel G S, Oscar E P, Eduardo E C, Willian R R and Helosia B 2012 Eur. J. Med. Chem. 50163

13. Angel A R D, Lorena F V, Isolda C M, Fernanda B C, Nivaldo L S and Heloisa B 2010 J. Braz. Chem. Soc. 21 1247

14. Paul V B, Gregory J W, Philip C S, Danuta S K and Des R R 2008 J. Biol. Inorg. Chem. 13107

15. Alagesan M, Bhuvanesh N S P and Dharmaraj N 2013 Dalton Trans. $\mathbf{4 2} 7210$

16. Nagwa N and Naseer M H 1999 Chem. Pharm. Bull. 47 944

17. Zheng K, Liu F, Xu X M, LiY T, Wu Z Y and Yan C W 2014 New J. Chem. 382964

18. Ganeshpandan M, Loganathan R, Suresh E, Rivasdeen A, Akbarsha M A and Palanindavar M 2014 Dalton Trans. 1203

19. Ramakrishnan S and Palaniandavar M 2008 Dalton Trans. 3866

20. Palchaudhuri R and Hergenrother P J 2007 Curr. Opin. Biotech. 18497

21. Ma D L, Shum T Y T, Zhang F, Che C M and Yang M 2005 Chem. Commun. 4675

22. Santhalingam K, Mendoza O, Durate A A, Mann D J and Vilar R 2013 Metallomics 5514

23. Basak S and Nagaraja V 2001 Nucleic Acids Res. 29 e105

24. Farrel N 1996 Adv. DNA Seque. Speci. Agen. 2187

25. Puckett C A, Ernst R J and Barton J K 2010 Dalton Trans. 391159

26. Crooke S T 1997 In Antisense Oligonucleotides in the Book Cancer Therapeutics Part II Experimental and Clinical Agents (New York: Springer) pp. 299-336

27. Ott R and Kramer R 1999 Appl. Microbiol. Biotechnol. 52761

28. Franklins S J 2001 Curr. Opin. Chem. Biol. 5201

29. Takasaki B K and Chin J 1994 J. Am. Chem. Soc. 116 1121

30. Preshagen E and Borbas E 2014 Coord. Chem. Rev. 27327430

31. Dos santos C M G, Andrew J H, Susan J Q and Gunnlaugsson T 2008 Coord. Chem. Rev. 2522512

32. Melanie B, Lilan K and Nicholas J L 2006 Chem. Soc. Rev. 35557 
33. Barta C A, Krishna S B, Jesica J, Thomspon K H, Kishore M W and Chris O 2007 Dalton Trans. 5019

34. Raja K, Suseelamma A and Hussain Reddy K $2015 \mathrm{~J}$. Iran. Chem. Soc. 121473

35. Pragathi M and Hussain Reddy K 2013 Indian J. Chem. 52A 845

36. Haribabu P, Hussain Reddy K, Patil Y P and Nethaji M 2012 Inorg. Chim. Acta 392478

37. Haribabu P, Hussain Reddy K, Patil Y P and Nethaji M 2013 Indian J. Chem. 52A 327

38. Pragathi M and Hussain Reddy K 2014 Inorg. Chim. Acta 413174

39. Siemens, SMART and SAINT 1996 Area Detector Control and Integration Software (Madison, Wisconsin, USA: Siemens Analytical X-ray Instruments Inc.)

40. Sheldrick G M 1990 Acta Crystallogr. Sec. A 46467

41. Sheldrick G M, 1997 SHELXS-97 Program for the Solution of Crystal Structures (Gottingen, Germany: University of Gottingen)

42. Brandenburg K and Putz H 2004 DIAMOND version 3.0 (Bonn: Crystal Impact)

43. Banerjee S, Mondal S, Chakraboty W, Sen S, Gachhui R, Butcher R J, Slawin A M Z, Mandal C and Mitra S 2009 Polyhedron 282785

44. Geary W J 1971 Coord. Chem. Rev. 781

45. Nakamoto K 1986 In Infrared and Raman Spectra of Inorganic and Coordination Compounds $4^{\text {th }}$ edn. (New York: Wiley)

46. Singh B and Singh T B 1999 Indian J. Chem. 38A 1286

47. Curtis N F and Curtis Y M 1965 Inorg. Chem. 4804
48. Yan P, Sun W, Li G, Nei C, Gao T and Yue Z 2007 J. Coord. Chem. 601973

49. Sinha S P 1966 Spectrochim. Acta 2257

50. Iftikar K, Sayeed M and Ahmad N 1982 Bull. Chem. Soc. Jpn. $\mathbf{5 5} 2258$

51. Sinha S P 1982 In Systematics and the properties of lanthanides, NATO ASI Series, Series C. Mathematical and Physical Sciences No. 109 (Holland: Kluwer Academic Publisher)

52. Carcelli M, Ianelli S, Pelagatti P, Pelizzi G, Rogolino D, Solinas C and Tegoni M 2005 Inorg. Chim. Acta 358 903

53. Dan J, Seth S and Chakraborty S 1988 Acta Crystllogr. Sect. C 451018

54. Sathyadevi P, Krishnamoorthy P, Alagesan M, Thanigaimani K, Muthiah P T and Dharmaraj N 2012 Polyhedron 31294

55. Wolff S K, Grimwood D J, McKinnon J J, Turner M J, Jayatilaka D and Spackman M A 2012 Crystal Explorer 3.1 (Crawley: University of Western Australia)

56. Jagadeeswara Rao Ch, Venkatesan K A, Nagarajan K, Srinivasan T G and Vasudeva Rao P R $2010 \mathrm{~J}$. Nucl. Mater. 39981

57. Selvi P T and Palaniandavar M 2002 Inorg. Chim. Acta 337420

58. Gopinathan H, Komathi N and Arumugham M N 2014 Inorg. Chim. Acta 41693

59. Song Y M, Xu J P, Ding L, Hou Q, Liu J W and Zhu Z L 2005 J. Inorg. Biochem. 103396

60. Pogozelski W K and Tullius T D 1998 Chem. Rev. 98 1089 